\title{
PENGEMBANGAN DESA WISATA BERBASIS KOMUNITAS DI YOGYAKARTA (STUDI KASUS: DESA WISATA SAMBI)
}

\author{
Adesty Lasally, Hafni Khairunnisa dan Akbar Abdurrahman Mahfudz. \\ Universitas Mahakarya Asia \\ Institut Agama Islam Negeri Syekh Nurjati \\ Universitas Mahakarya Asia \\ Email: adesty.lasally@gmail.com,hafni.k@gmail.comdanakbarabdul@gmail.com
}

\begin{abstract}
Tourism village is an embodiment of the concept of community-based tourism. Sleman has 37 tourism villages and Desa Wisata Sambi as a pioneer of tourism village since 2002. Sambi Village was chosen as the object of the research. The research aims to see the role of the component in developing community-based in Sambi. The research method uses quantitative and descriptive qualitative and used primary and secondary data. The results of the research are 1) the components of developing CBT consist of attractions, managerial capacity, community participation, amenities, marketing, accessibility, visitor, and asset ownership. 2) each component has a relationship in the development of the tourist village of Sambi. 3) managerial capacity component plays a crucial role in the sustainable development of Sambi Tourism Village; Results of the research are expected to become a reference for planning the development of CBT-based tourist destinations in Indonesia and Yogyakarta in particular.
\end{abstract}

Keywords: Sustainable Tourism, Rural Tourism, Sambi, and CBT.

\begin{abstract}
Abstrak
Desa wisata merupakan perwujudan dari konsep pariwisata berbasis komunitas (CBT). Kabupaten Sleman memiliki 37 desa wisata binaan. Desa wisata Sambi sebagai pioneer desa wisata di Kabupaten Sleman sejak tahun 2002 dipilih sebagai objek kajian penelitian. Penelitian bertujuan melihat peran komponen pengembangan daya tarik wisata berbasis komunitas di Desa Wisata Sambi. Metode penelitian menggunakan pendekatan kuantitatif dan deskriptif kualitatif. Jenis data yang digunakan berupa data primer dan data sekunder. Hasil penelitian yaitu pertama, komponen pengembangan daya tarik wisata berbasis CBT terdiri dari atraksi desa wisata, kapasitas manajerial, peran serta masyarakat, amenitas, pemasaran, aksesibilitas, kunjungan wisatawan, dan kepemilikan asset. Kedua, setiap komponen memiliki keterkaitan dalam perkembangan desa wisata Sambi. Ketiga, komponen kapasitas manajerial berperan krusial terhadap keberlanjutan pengembangan Desa Wisata Sambi. Hasil penelitian diharapkan dapat menjadi acuan perencanaan pengembangan daerah tujuan wisata berbasis CBT di Indonesia dan Provinsi D.I. Yogyakarta khususnya.
\end{abstract}

Kata kunci: Pariwisata Berkelanjutan, Desa Wisata, Sambi, dan CBT. 


\section{PENDAHULUAN}

Pariwisata global saat ini diakui sebagai salah satu industri terbesar di dunia. Pariwisata juga merupakan salah satu sumber penerimaan Produk Domestik Bruto (PDB) negara-negara di dunia. Pendapatan pariwisata internasional saat ini mencapai $7 \%$ dari keseluruhan ekspor barang dan jasa, meningkat $6 \%$ dari tahun 2014 (UNWTO, 2016). Pariwisata menempati rangking ketiga setelah minyak dan kimia dalam kategori ekspor dunia, berada di atas makanan dan produk otomotif.

Fenomena yang serupa juga terjadi di negara-negara berkembang, khususnya Indonesia. Penerimaan industri pariwisata di Indonesia mencapai 6.958 juta US\$ (2010), 9.119 juta US\$ (2013), 10.261 juta US\$ pada 2014 dan 10.761 US\$ pada 2015. Selama enam dekade terakhir, industri pariwisata terus berkembang. Pariwisata menciptakan banyaknya lapangan pekerjaan, usaha/bisnis pariwisata, pendapatan dan pengembangan infrastruktur. Destinasi pariwisata pun semakin beragam yang muncul, salah satu diantaranya adalah konsep pariwisata berbasis komunitas.

Konsep CBT merupakan konsep pengembangan pariwisata yang menekankan pada pembangunan pariwisata "dari masyarakat, oleh masyarakat dan untuk masyarakat". Prinsip utama CBT adalah pemberdayaan masyarakat. Masyarakat diwajibkan berperan aktif maupun komprehensif di setiap tahapan pengembangan pariwisata, baik perencanaan, pembangunan, pengelolaan, pengembangan, hingga tahap monitoring dan evaluasi Nuryanti (2015), Hadiwijoyo, (2012).

Konsep CBT juga bertujuan menciptakan keseimbangan dan keselarasan masing-masing kepentingan stakeholders dalam pengembangan pariwisata, seperti pemerintah, swasta dan masyarakat. Dalam konsep CBT masyarakat desa memiliki kedudukan yang sama dengan para stakehokder lainnya (Pantiyasa, 2019).

Pengembangan pariwisata berbasis komunitas pada hakekatnya harus memperhatikan beberapa poin penting, yaitu 1) Ekonomi "ketersediaan dana, terciptanya lapangan kerja, adanya pendapatan"; 2) Sosial "peningkatan kualitas hidup, kebanggaan komunitas, pembagian peran yang adil antara laki-laki dan perempuan, generasi muda dan tua, serta semakin kuatnya organisasi komunitas"; 3) Budaya "pemahaman mengenai carrying capacity area, pengelolaan sampah, dan kesadaran akan perlunya konservasi"; 4) Lingkungan "pemahaman akan carrying capacity area, pengelolaan sampah, dan kesadaran akan perlunya konservasi"; 5) Politik "partisipasi masyarakat lokal, peningkatan kekuasaan komunitas yang lebih luas, dan adanya jaminan hak-hak dalam pengelolaan SDA".

Salah satu bentuk konkret implementasi CBT adalah desa wisata. Desa wisata merupakan bentuk pengembangan dari wisata pedesaan (Rogi, 2015). Pariwisata pedesaan adalah pengembangan daerah pedesaan menjadi daerah tujuan wisata dengan menonjolkan berbagai keunikan yang ada, seperti lingkungan alam, flora dan fauna yang beraneka ragam, dan kehidupan sosial masyarakat pedesaan (Suhardjo, 2008). Putra (2016) menyatakan bahwa Selain daya tarik unik, pengembangan desa wisata juga harus didukung ketersediaan sarana pendukung berupa: i) akomodasi bersih dan nyaman (hotel dan fasilitas akomodasi untuk meningkatkan pelayanan selama dalam perjalanan); ii) fasilitas dan pelayanan pendukung untuk menambah kepuasan wisatawan (agen perjalanan, biro perjalanan, restoran dan tempat pelayanan makanan lain, took cinderamata, bank, pusat informasi, salon, fasilitas kesehatan, keamanan, polisi, dan pemadam kebakaran); iii) aksesibilitas (kenyamanan transport, kualitas jalan menuju ODTW baik dengan jarak tempuh terjangkau); iv) infrastruktur (ketersediaan sumber pemasok air bersih, listrik, tempat 
pembuangan limbah, kemudahan sarana komunikasi); dan v) kelembagaan (guna menjalankan aktifitas pariwisata, pengembangan, pengelolaan, pemasaran, promosi, pembuatan struktur organisasi, system control dan kebijakan investasi).

Pengembangan desa wisata juga harus memperhatikan prinsip, a) tidak bertentangan dengan adat istiadat atau budaya masyarakat desa setempat; b) pembangunan fisik ditujukan untuk meningkatkan kualitas lingkungan desa; c) memperhatikan unsur kelokalan dan keaslian; d) memberdayakan masyarakat desa wisata e) memperhatikan daya dukung, daya tampun, serta berwawasan lingkungan (Asyifa 2015).

Jika dilihat dari prinsip-prinsip dan kriteria pembentukan konsep pengembangan pariwisata berbasis komunitas (CBT) berupa desa wisata di atas, pengembangan desa wisata dianggap cocok diterapkan di Indonesia. Letak geografis masyarakat Indonesia yang Sebagian besar tersebar di perdesaan dapat dijadikan peluang menciptakan pemerataan peningkatan kesejahteraan ekonomi maupun sosial masyarakat (Suhardjo, 2008).

Daerah Istimewa Yogyakarta, khususnya Kabupaten Sleman merupakan salah satu kabupaten yang memiliki visi pengembangan pariwisata berkelanjutan berbasis komunitas (CBT), dari keberadaan Desa Wisata. Kabupaten Sleman memiliki 37 desa wisata binaan. Salah satu diantaranya adalah desa wisata sambi. Secara administrative Desa Wisata Sambi terletak di Padukuhan Dusun Sambi, Desa Pakembinangun, Kecamatan Pakem, Kabupaten Sleman. Desa ini merupakan salah satu pioneer desa wisata di Kabupaten Sleman. Berdasarkan hal tersebut, peneliti memilih Desa Wisata Sambi yang telah berdiri sejak tahun 2002 ini menjadi objek kajian penelitian.

Penelitian ini bertujuan melihat peran komponen pengembangan daya tarik wisata berbasis komunitas (CBT) di Desa
Wisata Sambi. Hasil penelitian diharapkan dapat digunakan sebagai bahan pertimbangan ketika membuat perencanaan pengembangan daerah tujuan wisata berbasis CBT, berupa desa wisata di Indonesia dan Provinsi D.I Yogyakarta khususnya.

\section{LITERATURE REVIEW}

Penelitian tentang desa wisata telah dilakukan oleh Zakaria dan Suprihardjo pada tahun 2014. Berlokasi di Desa Bandungan, Kecamatan Pakong, Kabupaten Pamekasan, Jawa Timur. Penelitian ini mencoba mencari tau tentang faktor-faktor yang mempengaruhi pengembangan desa wisata serta menentukan konsep pengembangan desa wisata. Variabel yang digunakan dalam penelitian ini adalah atraksi, amenitas, aksesibilitas dan SDM. Metode yang digunakan adalah kualitatif dengan pendekatan rasionalistik. Hasil penelitian menunjukkan bahwa faktor-faktor seperti kegiatan masyarakat desa sehari-hari, adat istiadat, serta faktor pendukung seperti aksesibilitas dan sarana-prasarana sangat mempengaruhi pengembangan desa wisata. Konsep pengembangan desa wisata sendiri diarahkan pada konsep spasial (rute perjalanan, sarana di desa wisata, dan infrastruktur). Konsep non-spasial yaitu menjadikan adat dan kebiasaan hidup masyarakat sebagai daya tarik utama (Zakaria, et al.: 2014).

Penelitian lain dilakukan oleh Ahsani, dkk (2018) tentang penerapan community based tourism (CBT) di desa wisata Candirejo, Borobudur. Variabel yang digunakan dalam penelitian ini adalah partisipasi masyarakat, community based tourism dan dampak. Metode penelitian yang digunakan adalah kualitatif. Hasil penelitian menunjukkan bagaimana implementasi community based tourism (CBT) yang telah dilakukan di desa wisata Candirejo. Hasil penelitian diketahui bahwa terdapat partisipasi masyarakat dengan memanfaatkan potensi desa serta didukung oleh bumdes. Desa wisata juga memberikan dampak yang positif kepada masyarakat baik dari sisi ekonomi, sosial maupun budaya. 
Khairunnisa (2019) dalam penelitian yang berjudul pengembangan pariwisata berbasis masyarakat di Blue Lagoon, Sleman, DIY bertujuan untuk mengetahui bagaimana pengembangan pariwisata berbasis masyarakat yang dilakukan di Blue Lagoon. Metode penelitian yang digunakan adalah deskriptif kualitatif. Variabel yang digunakan adalah strategi pengembangan dan komponen pengembangan desa wisata. Hasil penelitian menunjukkan bahwa pengembangan pariwisata yang telah dilakukan adalah dari sisi SDM, atraksi dan pemasaran.

Berdasarkan ketiga penelitian di atas, dapat diketahui tentang faktor-faktor dan variable-variabel yang merupakan pengembang keberadaan desa wisata. Variabel-variabel pengembang desa wisata yang dapat ditemukan dalam ketiga penelitian di atas adalah amenitas, SDM, atraksi, partisipasi masyarakat, aksesibilitas dan pemasaran. Pada penelitian ini untuk mengetahui bagaimana nilai masingmasing variabel pengembang desa wisata. Menggunakan indikator variabel pengembang desa wisata dari Direktorat Pemberdayaan Masyarakat tentang desa wisata. Pada penelitian ini bukan hanya mengungkap variabel apa saja yang merupakan pembentuk desa wisata tetapi melihat bagaimana kontribusi masingmasing variabel tersebut yang telah dikuantitatifkan sehingga dapat mengetahui secara pasti tentang kondisi variabel pengembangan desa wisata di Desa Wisata Sambi. Data sampel yang diambil pada penelitian ini adalah data pada dua tahun yang berbeda yaitu tahun 2013 dan 2016 . Hal ini bertujuan untuk melihat bagaimana progress pengembangan sebuah desa wisata dalam waktu tiga tahun.

\section{METODE PENELITIAN}

Lokasi penelitian dilaksanakan di Dusun Sambi, Desa Pakembinangun, Kecamatan Pakem, Kabupaten Sleman. Metode penelitian yang digunakan adalah mix method. Jenis data yang digunakan berupa data primer dan data sekunder. Data primer diperoleh langsung di lapangan dengan teknik pengumpulan data purposive sampling yaitu wawancara kepada pengurus desa wisata Sambi dan pihak berkepentingan. Wawancara dilakukan dengan memberikan sejumlah daftar pertanyaan terbuka dan tertutup. Data yang dikumpulkan dengan menggunakan kuesioner, yaitu Kapasitas manajerial dan pengelola, peran serta masyarakat, atraksi dan daya tarik wisata, amenitas, aksesibilitas, kepemilikan asset, tingkat kunjungan wisatawan, dan pemasaran. Data sekunder diperoleh dengan melakukan survey lapangan, disertai studi literature yang menunjang dan relevan dengan penelitian (baik berupa laporan-laporan dari instansi terkait, hasil penelitian terdahulu, dan sebagainya). Teknik analisis data menggunakan pendekatan deskriptif kualitatif - kuantitatif berfungsi menggambarkan atau menjelaskan fenomena yang diteliti (Sugiyono, 2017). Data-data yang telah terkumpul kemudian disajikan dalam bentuk deskripsi dan visual (grafik, gambar dan tabel) untuk memaparkan hasil interpretasi.

\section{KONSEP DASAR \\ Community Based Tourism}

Konsep pembangunan pariwisata berbasis masyarakat (Community Based Tourism) merupakan konsep pembangunan pariwisata yang menitikberatkan pada masyarakat sebagai kunci sukses dalam keberhasilan pembangunan pariwisata (Raharjana, 2012). Pembangunan pariwisata berbasis masyarakat merupakan bentuk pemberdayaan masyarakat sebagai salah satu stakeholder pariwisata. Masyarakat terlibat aktif dalam perencanaan, pelaksanaan dan evaluasi pariwisata (Demartoto, 2009).

Implementasi dari Community Based Tourism salah satunya adalah desa wisata. Desa wisata dalam pelaksanaannya menjadikan masyarakat sebagai pelaku utama dalam kegiatan wisata baik mulai dari 
perencanaan sampai evaluasi (Rogi, 2015). Desa wisata bukan hanya mampu meningkatkan perekonomian masyarakat melalui kegiatan wisata. Masyarakat juga dapat mengaktualisasikan kemampuannya dan mampu meningkatkan diri dari sisi sosial. CBT pun berperan sebagai alat untuk memperkuat organisasi masyarakat agar mampu mengatur kegiatan wisata di daerahnya. Hal ini karena masyarakat desa yang tergabung dalam organisasi akan menjadi pelaku utama dalam kegiatan wisata dan diberdayakan baik dari sisi sosial, ekonomi dan budaya.

\section{Kriteria Community Based Tourism}

Prinsip dalam pengembangan CBT adalah merujuk pada WTO (Nurhidayati \& Fandeli, 2012) adalah 1) Mengakui, mendukung dan mengembangkan kepemilikan komunitas dalam industri pariwisata; 2) mengikutsertakan anggota komunitas dalam memulai setiap aspek; 3) mengembangkan kebanggaan komunitas; 4) mengembangkan kualitas hidup komunitas; 5) menjamin keberlanjutan lingkungan; 6) mempertahankan keunikan karakter dan budaya di area lokal ; 7) membantu berkembangnya pembelajaran tentang pertukaran budaya pada komunitas; 8) menghargai perbedaan budaya dan martabat manusia; 9) mendistribusikan keuntungan secara adil kepada anggota komunitas ; dan 10) berperan dalam menentukan prosentase pendapatan (pendistribusian pendapatan) dalam proyek-proyek yang ada di komunitas

Kriteria yang harus dimiliki oleh desa wisata yang melaksanakan CBT adalah (Direktorat Pemberdayaan Masyarakat, 2013) :

1. Potensi \& Atraksi di Desa Wisata yang meliputi potensi alam di desa wisata yang berbasis keunikan sumber daya alam (SDA) sebagai daya Tarik utama; keunikan sumber daya budaya sebagai atraksi dan atau tradisi budaya; Potensi Sejarah (Non Bendawi dan Bendawi) yang terdapat di desa wisata; usaha atau kegiatan ekonomi kreatif berupa kerajinan makanan dan atau non makanan yang akan menjadi keunikan aktifitas ekonomi yang mampu menjadi daya Tarik utama; Keragaman (varian) atraksi dan atau tradisi yang masih dijalankan di desa setempat, dan Rutinitas/waktu pelaksanaan jenis atraksi dan atau tradisi di desa setempat.

2. Kapasitas Manajerial Pengelola Desa Wisata yang meliputi Kepengurusan dan Aktifitas Kelompok, Legalitas kepengurusan desa wisata, Administrasi Pertemuan Pengurus dan Transparansi Publik, dan Keuangan Kelompok.

3. Peran Serta Masyarakat yang meliputi Aktivitas Pariwisata; Pelibatan Masyarakat dan Dampaknya Bagi Lingkungan Desa Wisata.

4. Amenitas yang meliputi Sarana penginapan di desa wisata; Sarana MCK; Ketersediaan PLN dan Air Bersih; Kantor Kesekertariatan desa wisata; Sarana pertunjukan / sanggar termasuk alat musik, kostum dan kelengkapan pertunjukan; dan Sarana Penunjang : Souvenir Shop.

5. Pemasaran dan Promosi yang meliputi Pemasaran yang dijalankan desa wisata, Keterlibatan dan Kesediaan melakukan promosi, dan Pengembangan program/ paket wisata di desa wisata.

6. Kondisi dan Sarana Aksesibilitas

7. Kunjungan Wisatawan

8. Kepemilikan Asset di Desa Wisata.

\section{PEMBAHASAN DAN DISKUSI}

Komponen unsur-unsur pengembangan pariwisata berbasis CBT di Desa Wisata Sambi terdiri dari potensi dan daya tarik wisata, kapasitas manajerial, peran serta masyarakat, amenitas, pemasaran, aksesibilitas, kunjungan wisatawan, dan kepemilikan asset.

Potensi dan daya tarik wisata berupa outbond yang dimiliki dan dikelola oleh investor (pihak luar). Atraksi yang diadakan di desa wisata nyaris sudah tidak ada lagi. Kapasaitas manajerial, terdapat pokdarwis yang mana bersifat mati suri. Pengurus tidak 
aktif dan memiliki kesibukan masingmasing. Kepengurusan hanya sebatas sebagai sebagai simbol keanggotaan. Usaha outbond, jeep dan Sambi resort sendiri dikelola oleh pihak luar desa wisata. Peran serta masyarakat dapat dikatakan tidak ada karena masyarakat hanya dilibatkan jika ada permintaan khusus dari pengelola outbond untuk membantu. Amenitas secara umum sudah baik dan lengkap, akan tetapi keseluruhan bukan dimiliki oleh pihak desa wisata Sambi.

Pemasaran dilakukan oleh masingmasing pemilik atraksi yang ada di kawasan Desa Sambi, sehingga sudah dipastikan desa wisata tidak lagi ikut andil dalam kegiatan pariwisata. Aksesibilitas di kawasan Desa Wisata sambi sudah sangat layak, baik dari segi jalan utama, maupun jalan di dalam kawasan desa wisata. Kunjungan wisatawan hanya berkunjung ke outbond atau Sambi resort dan bukan mengunjungi Desa Wisata Sambi. Kepemilikan Aset, tanah kas desa dimiliki oleh desa. Pihak outbond ledoksari dan sambi resort sebagai investor luar berstatus menyewa tanah kas desa. Pihak desa mendapat keuntungan dari penyewaan tanah kas desa dan mendapat kompensasi atas setiap kunjungan wisatawa.

Unsur-unsur pembentuk di atas akan dipaparkan pada grafik 1 di bawah ini:

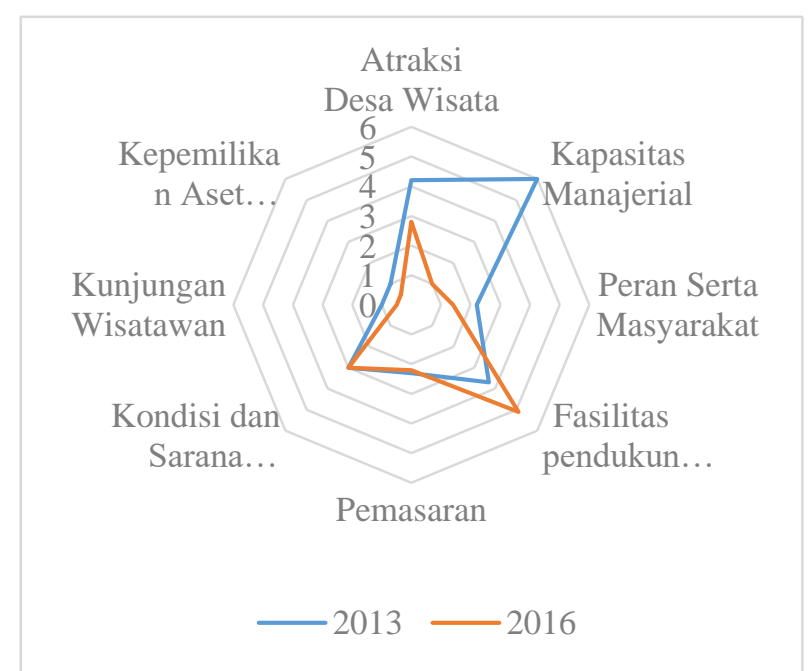

Sumber: Olah Data Penulis (2013 dan 2016)

\section{Grafik 1. Komponen Pengembangan Desa Wisata Berbasis Komunitas (CBT) di Desa Sambi Tahun 2013 dan 2016}

Dari grafik di atas, diketahui bahwa potensi dan daya tarik wisata di Desa Wisata Sambi di tahun 2013 (skor 4,2) dan 2016 (skor 2,8), kapasitas manajerial di tahun 2013 (skor 6) dan 2016 (skor 1), peran serta masyarakat tahun 2013 (skor 2,2) dan 2016 (skor 1,4), amenitas tahun 2013 (skor 3,7) dan 2016 (skor 5,1 ), pemasaran (skor 2,3) dan 2016 (skor 2,2), aksesibilitas tahun 2013 (skor 3) dan tahun 2016 (skor 3), kunjungan wisatawan tahun 2013 (skor 1) dan 2016 (skor 0,5), dan kepemilikan asset tahun 2013 (skor 1) dan 2016 (skor 0,5).

Aksesibilitas menuju Desa wisata Sambi melewati sebagian besar jalan beraspal dengan waktu tempuh sekitar 30 menit dari Kota Yogyakarta. Akses jalan dan waktu tempuh yang relatif singkat menunjukkan tingkat aksesibilitas di Desa Wisata Sambi cukup baik ditambah dengan kapasitas jalan yang dapat dilewati kendaraan roda dua maupun roda empat. Selain itu, Desa Wisata Sambi juga mudah terjangkau, karena sudah tersedia kendaraan angkutan umum lokal menuju Desa Wisata Sambi dengan jurusan yogyakarta - kaliurang. Wisatawan yang datang dapat langsung menuju pintu Desa Wisata Sambi. Grafik 1 menunjukkan bahwa komponen aksesibilitas masih memiliki nilai sama, baik di tahun 2013 (3) dan tahun 2016 (3).

Hasil analisis dari grafik 1 menunjukkan adanya gejala penurunan perkembangan desa wisata yang diamati dari setiap komponen baik dari potensi dan daya tarik wisata, kapasitas manajerial, peran serta masyarakat, pemasaran, kunjungan wisatawan, dan kepemilikan asset di tahun 2013 dan 2016. Satu-satunya komponen yang mengalami peningkatan adalah dari aspek amenitas yaitu peningkatan ketersediaan fasilitas pendukung desa wisata seperti homestay, mck, air, dan listrik di tahun 2013 ke tahun 2016. 
Penyebab utama dari penurunan pengembangan Desa wisata Sambi adalah dari aspek manajerial dan peran serta masyarakat yang berkurang signifikan di desa wisata Sambi sehingga ikut mempengaruhi penurunan komponenkomponen lainnya. Wawancara dengan sekretaris pengelola desa wisata, diketahui bahwa pengelolaan di Desa wisata Sambi sudah murni dikelola oleh masing-masing pengusaha, pengurus tidak terlibat lagi dalam kegiatan pengelolaan desa wisata. Pengelola desa wisata hanya berfungsi dari sisi legitimasi saja, dan hanya mendapat laporan tentang kegiatan wisata di desa dari usaha-usaha privat dan minim campur tangan terhadap kegiatan wisata desa.

Hasil analisis menunjukkan berkurangnya peran serta masyarakat dan manajerial desa wisata Sambi dapat ditinjau beberapa hal, yaitu: pertama, potensi dan daya tarik wisata tidak lagi dikelola oleh Desa wisata Sambi. Kedua, Daya tarik wisata Desa wisata Sambi sebagian besar dikelola oleh pihak swasta, baik atas nama badan usaha yang bersifat perseorangan atau swasta. Hal tersebut diketahui dari pernyataan pengelola outbound maupun sektretaris Desa wisata Sambi.

"Disini itu ada jeep, ada resort, ada restoran, ada outbond! Semuanya punya pemilik masing-masing! Punya tamu masing-masing! Cari tamu juga masing-masing! Ya paling, kalau ada tamu jeep mau makan, bisa diarahkan ke restoran, tamu restoran mau outbond biasanya diarahkan kesini! (Sumber 2, 2016)".

Komponen-komponen yang turut dipengaruhi penurunan aspek manajerial dan peran serta masyarakat diantaranya adalah tidak berkembangnya potensi dan daya tarik wisata di Desa wisata Sambi dari tahun $2013(4,2)$ ke $(2,8)$ tahun 2016. Keadaan tersebut diketahui dari pernyataan sekretaris desa wisata Sambi bahwa potensi desa wisata utamanya berbasis lingkungan alam didukung dengan sarana outbound seperti flying fox, kano, kolam renang dan tidak mengalami perubahan signifikan dari tahun 2013 hingga tahun 2016.

"Potensi di Desa Sambi ya alam, pertanian, sungai, ada juga outbond ya, flying fox, kano, kolam renang intinya mbak, potensi masih sama seperti dulu! (Sumber 1, 2016)".

Penemuan mengenai unsur-unsur pengembang Desa Wisata Sambi di atas, bertolak belakang dengan hasil penelitian yang dilakukan oleh Saputro (2014) yang mengatakan bahwa daya tarik wisata di Desa Wisata Sambi berkembang lebih bervariasi. Selain itu, dari hasil observasi lapangan juga diketahui bahwa variasi kegiatan, amenitas, pemasaran, jumlah kunjungan wisatawan di Desa Sambi dari tahun 2013 ke 2016 mengalami peningkatan. Namun, sayangnya hal tersebut terjadi karena adanya peran pihak swasta dan bukan atas nama desa wisata. Komponen manajerial yang terus menurun dan akhirnya vakum, berdampak juga terhadap peran masyarakat dalam kegiatan desa wisata. Kepemilikan asset pariwisata yang hampir keseluruhan dimiliki oleh pribadi atau pihak swasta, tentunya memiliki kebijakan masingmasing, termasuk kebijakan memperkerjakan atau tidak pegawai. Pihak swasta berjalan sendiri-sendiri dan menarik diri dari desa wisata.

Penelitian yang dilakukan oleh Yulianto (2015) menyatakan bahwa yang menjadi penyebab menurunnya manajerial Desa Wisata Sambi yaitu rendahnya nilai sosial sumber daya manusia. Nilai sosial tersebut yaitu jaringan, peran serta, kelembagaan, objek wisata, dan manfaat. Rendahnya nilai sosial SDM yang ada di Desa Wisata Sambi menyebabkan investor/pihak swasta masuk. Kelembagaan dengan sistem manejerial yang tidak kuat, menyebabkan kepengurusan Desa Wisata Sambi sedikit demi sedikit menurun. Kelembagaan yang tidak kuat secara tidak langsung berdampak terhadap menurunnya unsur-unsur pengembang pariwisata lainnya, walaupun jika dilihat di lapangan, unsur-unsur tersebut 
berkembang pesat karena adanya pihak swasta.

\section{KESIMPULAN}

Komponen pengembangan daya tarik wisata berbasis CBT di Desa Wisata Sambi terdiri dari atraksi wisata, kapasitas manajerial, peran serta masyarakat, amenitas, pemasaran, aksesibilitas, kunjungan wisatawan, dan kepemilikan asset. Setiap komponen pengembangan daya tarik wisata memiliki peranan yang saling berkaitan dalam perkembangan desa wisata Sambi. Komponen kapasitas manajerial dan peran serta masyarakat berperan krusial terhadap keberlanjutan pengembangan Desa Wisata Sambi. Pada data tahun 2016 menunjukkan bahwa menurunnya kapasitas manajerial dan peran serta masyarakat juga berpengaruh terhadap komponen lainnya yang akhirnya menyebakan pengembangan Desa Wisata Sambi menjadi menurun dan kurang maksimal.

Hasil penelitian ini diharapkan mampu menjadi bahan pertimbangan bagi para pemegang kebijakan dalam pengembangan desa wisata. Hal utama dalam pengembangan desa wisata adalah terletak pada sisi manajemen dan peran serta masyarakat. Kualitas daya Tarik wisata yang tinggi jika tidak didukung oleh peran serta masyarakat dan kemampuan manajerial yang baik maka akan menjadi tidak maksimal dalam pengembangan pariwisata. Berbanding terbalik dengan kemampuan SDM, peran serta masyarakat dan manajeriak yang bagus mampu membuat daya Tarik atau potensi yang terlihat biasa saja menjadi maksimal.

\section{DAFTAR PUSTAKA}

Ahsani, R., Suyaningsih, O., Ma'rifah, N., Aerani. (2018). "Penerapan Konsep Community Based Tourism (CBT) di Desa Wisata Candirejo Borobudur Mewujudkan Kemandirian Desa". Jurnal Ilmu Administrasi Publik: Publisia, Vol. 3 No. 2 hlm. 135 - 146.

Arsanti, V. (2012). Partisipasi Masyarakat dalam Pengembangan Desa Wisata Dusun Sambi Desa Pakembinangun Kecamatan Pakem Kabupaten Sleman. Retrieved from Electronic Thesis \& Disertasi Universitas Gadjah Mada Yogyakarta.

Asyifa, W.A. (2015). Partisipasi Masyarakat dalam Pengembangan Pariwisata Di Desa Wisata Alamendah Kabupaten Bandung. Diperoleh Dari Electronic Thesis \& Disertasi Universitas Gadjah Mada Yogyakarta.

Direktorat Pemberdayaan Masyarakat. (2013). Buku Panduan Kriteria Pengembangan Desa Wisata. Kementerian Pariwisata dan Ekonomi Kreatif. Jakarta.

Hadiwijoyo, S.S. (2012). Perencanaan pariwisata pedesaan berbasis masyarakat (sebuah pendekatan konsep). Yogyakarta: Graha Ilmu.

Khairunnisa, H. (2019). "Pengembangan Pariwisata Berbasis Masyarakat di Blue Lagoon, Sleman, Yogyakarta". Islamic Management and Empowerment Journal: IMEJ, Vol. 1 No. 2 hlm. $205-216$.

Nugroho, I. (2011). Ekowisata dan Pembangunan Berkelanjutan. Yogyakarta: Pustaka Pelajar.

Nurhidayati, S.E., Fandeli, C. (2012). "Penerapan Prinsip Community Based Tourism (CBT) Dalam Pengembangan Agrowisata di Kota Batu, Jawa Timur". Jejaring Administrasi Publik. Vol. 4, No. 1. Hlm. 36 - 46.

Nuryanti, W. (2015). The Power Of Culture In Sustainable Development. International Conference Culture in the Post-2015 Sustainable Development 
Agenda. May, 15, 2015. Hangzhou $-\mathrm{RRC}$.

Pantiyasa, I.W. (2019). "Konstruksi Model Pengembangan Desa Wisata menuju Smart-Eco Tourism di Desa Paksebali, Klungkung, Bali”. (2019). Jurnal Kajian Bali, Vol. 09, No. 01, Hal. 165 - 188.

Putra, I.N.D. (2016). Pariwisata Berbasis Masyarakat Model Bali. Denpasar: Prasasti.

Raharjana, D. T. (2012). "Membangun Pariwisata Bersama Rakyat: Kajian Partisipasi Lokal dalam Membangun Desa Wisata di Dieng Plateau". Jurnal Pariwisata, Vol 2, No. 3.

Rogi, C.H. (2015). Dinamika Pengembangan Desa Wisata Brayut di Kabupaten Sleman. Diperoleh dari Electronic Thesis \& Disertasi Universitas Gadjah Mada Yogyakarta.

Saputro, F.D. (2014). Pengembangan Atraksi di Desa wisata Ledok Sambi Kabupaten Sleman. Retrieved From Electronic Thesis \& Disertasi Universitas Gadjah Mada Yogyakarta Tesis.

Sugiyono. (2017). Metode Penelitian Kombinasi (Mixed Methods). Bandung: Alfabeta.
Suhardjo, A.J. (2008). Geografi Pedesaan Sebuah Antologi. Yogyakarta: Ideas Media.

Triambodo, S. (2015). Analisis Strategi Penguatan Kelembagaan Desa Wisata Berbasis Ekonomi Kreatif (Studi di Desa Wisata Kerajinan Tenun Dusun Gamplong, Desa Sumberrahayu, Kecamatan Moyudan, Kabupaten Sleman, DIY). Diperoleh dari Electronic Thesis \& Disertasi Universitas Gadjah Mada.

UNWTO (World Tourism Organization) (2016). Tourism Highlight 2016 Edition. Diperoleh dari http://mkt.unwto.org/publication/unwt o-tourism-highlights-2016-edition

Yulianto, T.S. (2015). Modal Sosial Masyarakat Dalam Pengembangan Pariwisata Di Desa Wisata Pentingsari dan Sambi Kabupaten Sleman. Diperoleh dari Electronic Thesis \& Disertasi Universitas Gadjah Mada Yogyakarta.

Zakaria, F. dan Suprihardjo, R. (2014). "Konsep Pengembangan Kawasan Desa Wisata di Desa Bandungan Kecamatan Pakong Kabupaten Pamekasan". Jurnal Teknik Pomits, Vol. 3 No. 2 hlm. C245-C249. 